\title{
DEMOLISHING THE PRESENT TO SELL OFF THE FUTURE? THE EMERGENCE OF 'FINANCIALIZED MUNICIPAL ENTREPRENEURIALISM' IN LONDON
}

\author{
Joe Penny \& Joe Beswick* \\ * The authors contributed equally to this work
}

\begin{abstract}
This article introduces a new mode of urban entrepreneurialism in London through a study of the state-executed, speculative development and financialization of public land. In response to an intensifying housing crisis and austerity-imposed fiscal constraints, municipalities in London are devising entrepreneurial solutions to deliver more housing. Among these 'solutions' can be found the early signs of the state-executed financialisation of public housing in the UK with the use of speculative council-owned Special Purpose Vehicles (SPVs) that replace existing public housing stock with mixedtenure developments, creating ambiguous public/private tenancies that function as homes and globally tradable assets. Drawing together parallel literatures on the financialization of entrepreneurial urban governance and housing, and combining these with original empirical research, we situate these developments in contrast to earlier modes of entrepreneurialism, identifying a distinct mode of entrepreneurial governance in London: Financialized Municipal Entrepreneurialism. The local state is no longer merely the enabler - limited to providing strategic oversight of the private sector - but financializes its practice in a reimagined interventionism, as property speculator. This article concludes that while the architects of this new mode of entrepreneurialism extol the increased capacity and control it provides, any such gains must be set against longer-term financial, democratic, and political risks.
\end{abstract}

\section{Introduction}

"The absence of the state from the building of social housing is wrong. We're getting back into it in a totally different way than before... But the fact that we have to do things differently shouldn't stop us. It cannot be the fear of doing things differently that gets in the way of actually building social housing in London. So it's got to work... it's got to work" (Lambeth Councillor).

This paper introduces and explores a new mode of urban entrepreneurialism in London through a study of the state-led, speculative development and financialization of public land, including public housing estates. Amidst an intensifying housing crisis, exacerbated since 2010 by the ideological pursuit of 'austerity', a number of local authorities in the capital, faced with their own fiscal crises, are actively devising entrepreneurial solutions beyond providing state-funded public housing, which they can no longer do, or relying on diminishing gains from private-sector developers. Amongst these solutions is the London Borough of Lambeth's newly constituted Special Purpose Vehicle (SPV), Homes for Lambeth $(\mathrm{HfL})$, a council-owned, speculative real-estate company, that will demolish existing public housing stock and deliver mixed-tenure developments, creating ambiguous public/private tenancies that function as both homes and globally tradable assets. More than an isolated case of municipal innovation, we situate $\mathrm{HFL}$ and numerous other council-owned real estate SPVs across the city, at the leading edge of an emerging mode of entrepreneurial governance - termed here financialized municipal entrepreneurialism. Whilst the architects of this new approach claim that it increases the local state's capacity and control, we suggest that any such gains must be set against longer-term financial, democratic, and political risks that will ultimately be borne by residents. 
Through a detailed analysis of the case of $\mathrm{HfL}$, we explore this mode of entrepreneurialism and focus in particular on the under-theorised role of the state in processes of financialization, asking why, how, to what extent, and with what implications, local government and its historic housing estates are being financialized. To answer these questions, the paper draws together parallel literatures on entrepreneurial urban governance and its financialization, and the financialization of housing, and combines these with original empirical research. The paper shows that in order to generate income and build more homes, including affordable homes, Lambeth Council, like numerous other authorities across the city, are playing an active role in the financialization of their public housing estates. Council-owned SPVs are opening up a smooth governance space, outside of a number of financial and regulatory constraints imposed from above, enabling Councils to act commercially and speculatively, by building private homes to sell and rent and by providing an enhanced role for financial capital in the housing of London's low-income population.

In charting the emergence of council-owned SPVs, we seek to make the following theoretical and empirical contributions to our understanding of the nexus of financialization, statecraft, and housing in London and beyond. First, we confirm a financializing dynamic rooted in the active pursuit of political and fiscal capacity in the context of unequal scalar-state relations, with financialization operating as an urban governance ' $f i x$ '. Secondly, we contribute to an emerging literature concerned with the financialization/state nexus - "one of the research frontiers to be pushed in the coming years" (Aalbers 2017: 10) - by providing new evidence of the role of the state in processes of financialization: More than the facilitator and enabler of financialization, Lambeth Council is its active executor constituting public housing estates as new sites of extraction for financial capital. Thirdly, we evidence the permeation of financial practices into new residential spaces, broadening our understanding beyond owner-occupation and contributing to the nascent literature on rental housing as "an important new node for financializing projects globally" (Fields, 2017: 1; cf. Aalbers 2017). Finally, we situate the developments in contrast to earlier modes of entrepreneurialism, exploring a distinct mode of entrepreneurial governance in London, in which the local state is no longer limited to providing strategic oversight to the private sector, but rather initiates financialization in order to develop its fiscal and political capacity to intervene in the housing market.

To substantiate these claims, in the next section, we introduce the paper's core concepts by drawing together literatures on urban entrepreneurialism and the financialization of urban governance and housing. The relative paucity of studies that address head-on the role of the local state in processes of financialization (Aalbers, 2017), on the one hand, and the "underresearched and under-theorized" area of housing financialization generally (ibid: 2), and of public rental housing, on the other, is highlighted. In the fourth section, we situate the SPV in the context of the decline and failure of two proceeding modes of public housing delivery and governance, and detail the financialized municipal entrepreneurialism which is emerging as a new variant of entrepreneurial governance in the city. Finally, in the fifth section, we explore the precise nature and implications of the Janus-faced affordable housing delivered through $\mathrm{HfL}$, as both globally tradeable financial assets and quasi-public, partially decommodified homes.

\section{The Financialization of Urban Governance and Housing}

In October 2015 the London Borough of Lambeth's Executive Cabinet approved a plan to form Homes for Lambeth (HfL), a wholly council-owned Special Purpose Vehicle (SPV) that would enable the Council "to act in a truly commercial way... effectively as a property developer" (Lambeth 2015: 13) and secure funding from "the open market and institutional investors" (Ibid: 2) to build market homes, cross-subsidising the development of some affordable homes. HfL represents a significant shift in local government practice with regards to housing in the UK context, and signals a step-change from earlier 
modes of entrepreneurial governance. For the three decades after the Second World War, the state, through local authorities, was a major, and at times dominant, builder of (public) housing, with annual output topping 300,000 homes. By the late 70 s, however, the local state's role in housing production was diminished, such that in 1999 the number of homes built by local authorities numbered just 54 (Davis 2013). The new model presented here signals a clear break from this decline: Councils are once again directly building housing in London More significant than this however, is how they are building homes. Under the new model, Lambeth Council are eschewing private-developer partnerships whilst drawing on the techniques and resources of financial capitalism, treating their land as a financial asset, and constituting public homes as a proto-financial asset class. More than just a novel model of housing production, $\mathrm{HfL}$ represents an incipient mode of urban entrepreneurialism - a form of financialized municipal entrepreneurialism, predicated on speculative residential real-estate development and enhanced engagement with capital markets. To situate the case of $\mathrm{HfL}$, substantiate its significance as a new variant of urban entrepreneurialism in the UK, and foreground its likely implications for tenants and local politics, this section brings together literatures on the financialization of urban (entrepreneurial) governance and housing.

\subsection{Urban Entrepreneurialism and the Financialization of Urban Governance}

The transition towards entrepreneurial forms of urban governance has been one of the central concerns of critical urban studies over the past 25 years, and has been well documented and verified in the ever expanding literature on the now-not-so-new New Urban Politics (MacLeod \& Jones, 2011). David Harvey's (1989) formative account of the shift from post-war 'managerial' logics and regimes of urban governance to their entrepreneurial equivalents in the neoliberal era has been found to hold, to varying extents, across multiple scales and national boundaries, such that a consensus can be seen in urban politics in which the positive benefits of city governments pursuing growth through development is taken as axiomatic (Davidson \& Iveson 2015).

In the US, much of the literature on this shift from urban managerialism to entrepreneurialism emerged amidst ascendant New Right ideologies and the retrenchment of Federal support to states and municipalities at a time of uneven growth, deindustrialisation, and increasingly globalizing and deterritorializing flows of capital investment (DeFilippis 2004). Predictably and purposefully, this ushered in a sink-or-swim politics, "that only a fortunate few could realistically expect to win" (Peck \& Whiteside, 2016: 241), wherein "urban administrations were increasingly compelled to compete with other city governments in an endeavour to attract hyper-mobile investment and wealth generating entrepreneurs..." (MacLeod \& Jones, 2011: 2443). Concurrently, city governments turned away from engaging in distributional politics around issues of collective consumption, which were recast as fiscal millstones around municipal necks (Cochrane 2007). Indeed, the role of the local state, operating alongside local business interests in 'growth coalitions' (Logan \& Molotch 1987), or through quasi-public vehicles and public-private partnerships, was reconfigured along more speculative and risk-taking lines towards the facilitation, often via generous bond-raised public subsidies and investment, of private-led land and real-estate development, the construction of megaprojects, and the hosting of one-off sporting and cultural events.

In the UK, the turn towards urban entrepreneurialism began in the late 1970s under a Labour Government that sought to promote economic regeneration through state initiative to reduce urban inequality (Cochrane 2007). But it was during the Thatcher years that the New Urban Politics of economic competiveness (of firm and city), privatism, and privatisation was embraced (Barnekov et al. 1989). In step, and in contact, with policy makers across the Atlantic, increased faith was placed in private sector actors and market dynamics to address "a range of social and - above all - economic problems" (Cochrane 2007: 89) for which the state was held culpable. Whilst the logic of entrepreneurialism played out in distinct ways in the different institutional context of the UK, 
supplementing rather than supplanting managerial logics (Hall \& Hubbard 1996), faith in the private sector and in competitiveness fast became a powerful urban policy doxa. As Hall and Hubbard noted (1996: 157) "the political rhetoric of the 1980s clearly positioned the private sector as the key actor in city rebuilding..." - the state was to contribute strategic oversight, and resources, to this process. Nowhere has this been more apparent than in housing policy, where "from the late 1980s, the Conservative Government of the day started to promote the idea that local authorities should be 'enablers' rather than direct providers of housing" (Davis 2013: 62), relying on private and voluntary sector organisations for public housing construction and management- an attitude that has been consistent ever since, expressed in the ascendency of the planning gain model of affordable house building and the large-scale public housing stock transfers from local government to Housing Associations (Watt 2009).

It is very much out of this entrepreneurialised urban governance landscape, shaped in the US, and increasingly the UK, by tightly imposed fiscal constraints from above, shrinking tax revenues (either by falling tax bases and/or legal limits on tax increases) and an existential need to engage in city 'boosterism', that the turn towards financialization has been noted, as city governments seek new ways to achieve public policy objectives (Weber 2010; Leitner 1990). In recent years an insightful series of studies, focussing on US cities, has emerged detailing how already entrepreneurialised city governments have enabled and employed means, vehicles, and tools of finance capital across various arenas of local government activity, including urban redevelopment (Rutland 2010), urban infrastructure (Ashton et al. 2016), Tax Incremental Financing (Pacewicz 2013), post-natural disaster redevelopment (Gotham 2016) and debt-led growth strategies (Kirkpatrick \& Smith 2011). In constrained fiscal contexts, these cases show how municipal governments in the US are increasingly reliant on capital markets and converting income streams from local public assets into financial products, often in order to catalyse the same kinds of speculative, growth-oriented, and privately delivered development projects associated with previous rounds of urban entrepreneurialism. Whilst not entirely novel, these municipal entanglements with the actors, logics, and techniques of global finance seem to be intensifying as "the dependency of political institutions on financial markets for securing investment capital" (Gotham 2016: 1363) has increased. Indeed, employing an explicitly conjunctural optic, Peck and Whiteside (2016) and Peck (Peck 2016) identify a general logic of financialized urban governance across cities, suggesting that the municipal state in the US has become a critical terrain, target, and agent of financialization, amounting to the constitutive financialization of late-entrepreneurial metropolitan governance, about which we currently know little (Peck \& Whiteside, 2016: 237).

Hamstrung by budgetary cutbacks imposed from above, a key driver of municipal financialization that emerges from the literature is the search for enhanced fiscal and political capacity, however temporarily or contingently attained. Top-down austerity policies can be said to be one of the key drivers of financialization at lower and subordinated levels of government. In the case of US cities, recourse to capital markets through revenue bonds and TIFs became commonplace when fiscal federalism reduced transfers to state and city governments (Hackworth 2002) and as state governments moved to curtail the power of city governments to raise local taxes (Davidson \& Ward 2014). In the UK context, the Hammersmith \& Fulham derivatives debacle in the early 1990s occurred in large part because of Thatcher's rate-capping and Rate Support Grant controls and reductions (Tickell 1998). More contemporaneously, the politics of 'austerity localism' (Featherstone, et al., 2012), coupling unprecedented budget cuts and centrally imposed limits on local taxation, with local funding incentives/exigencies around economic growth and house building (Penny, 2016; Sandford, 2016), is now pushing London's local authorities towards capital markets and financial practices, something much less developed than in the US. 
In a context where cities must become ever less reliant on funds redistributed from higher levels of government, local state actors are innovating "to devise revenue generating mechanisms themselves" (Davidson \& Ward, 2014: 86) by opening up new opportunities for investors through, for example, "interest-rate swaps, derivatives, and securitized revenue streams" (Peck \& Whiteside, 2016: 242). Meanwhile, it has been observed that states and state-like actors, under pressure from financial markets, are themselves ingesting financial ways of working (Hackworth 2007), such that "financial narratives, practices and measurements are dominating branches of government, public authorities and semi-public institutions" (Aalbers 2017: ). Yet, whilst the forces acting on local actors may be commonly experienced across space, producing discernible multi-sited patterns of practice, local responses can also be expected to be variegated and contingent. City governments, as Ward (2016: 3) reminds us, are "more than the puppets of financial capital" and are not simply, as Gerald Davis (2009) has it, "managed by the markets". At the interface of the local state and processes of financialization this means, therefore, investigating why, how, to what extent and under what conditions the local state is engaging in practices of financialization, or is being financialized, and with what implications. As examples of the local state's financialization grow under normalised conditions of 'austerian' rule, problematizing the local state's role in financialization is fast becoming an urgent "research frontier" (Aalbers 2017: 10) and indeed political task for critical urban studies: the nascent literature on the subject suggests that although pursuing statecraft and public policy objectives through financial means may buy fiscal and political capacity for the local state, it does so at a cost (Pacewicz 2013; Ashton et al. 2016).

\subsection{The financialization of public/non-market housing}

Municipal financialization is analysed in this paper through the novel means by which a London Council is regenerating its public housing estates. However, the role of housing here is more than an incidental policy-node through which this variant of entrepreneurial governance is expressed. As with earlier forms of entrepreneurial governance, housing, or rather real-estate, is crucial to the model. First, the speculative mode of governance outlined in this paper is predicated on the council's treatment of its land assets and public housing in a financialized manner. Secondly, alongside developing high-value private housing, the model produces a form of quasi-public and financialized affordable housing which is unlike previous forms of public housing produced in the UK. Housing financialization, often overlooked in studies of financialization (Aalbers, 2017)must therefore be a cornerstone of our analysis.

Much of the existing research into the financialization of housing emerged in the wake of the foreclosure crisis, focussing on a single tenure: mortgaged owner-occupation. Following the foreclosure crisis, a series of studies carefully detailed the recurrent intensifications of the housingfinance link, and the production of a global marketplace for synthetic financial products grounded in (subprime) household mortgages (Aalbers 2012; 2016; Fox-Gotham 2009; Newman 2009). These studies reveal how, over the course of about a quarter century, financializing innovations, alongside de- and re-regulations (Aalbers, 2016), created liquid, tradeable assets out of spatially-fixed homes (Fox-Gotham 2009), de-linking home and wealth from place. Mortgage credit was used as the basis for complex, collateralised investment products, and the homes and neighbourhoods of low-income households, previously scarcely touched by financial capital, became key sites of extraction. Credit was expanded in exchange for a decoupling of control and the effect was often to entrench, not disrupt, urban inequality.

Notwithstanding the importance of these studies, they can only offer a partial contribution to our understanding of the financialization of housing, which is neither a monolithic process (Aalbers, 
2017; Fields 2017), nor one that is limited to owner occupation, or mortgage markets. While the variegated nature of financialization is generally acknowledged, understanding of the financializing dynamics in non-owner occupation tenures, or within non-commodified or public housing is scant. In recent years some of the first explorations of the ways in which non-market housing can be financialized, through development funding and the trading of financial assets and liabilities, have emerged ((Aalbers et al, 2017; Wainwright \& Manville, forthcoming). Centring on the novel use of bonds and derivatives by Dutch and UK Housing Associations (HAs), these studies have found financial institutions eager for investment portals into non-market housing, and HAs innovating financially in response to reduced central funding, with a growing commercialisation of the sector. Wainwright and Manville's (forthcoming) analysis of HAs in the UK brings into sharp focus the contradictory public/private obligations produced in the financialization of a sector whose core values - affordable housing for those on low-incomes - are "diametrically opposed" (ibid: 3 ) to the methods and motives of the financial sector. Financialization has enabled HAs to access development capital in a time of limited resource, but this requires a shift in operational approach away from social and public policy oriented frameworks, towards a commercial, financial agenda focussed on "'asset management', valuations and risk modelling" (ibid: 6$)^{1}$

In another context, Desiree Fields' (Fields 2013; Fields 2017; Fields \& Uffer 2016) work on the financialization of private rent-regulated housing in New York and Berlin illustrates how residential financialization can occur through the transfer of housing to a financial sector actor. Her work, detailing the financialization of New York's private rent-stabilised housing stock, identifies rental housing as a "frontier for financialization", a dynamic that she notes is "increasingly relevant since the global financial crisis" (Fields, 2017: 1; see also Beswick et al 2016). Financialization is operationalised in Fields' work as the purchase of rent stabilised housing by private equity funds, and the funds' treatment of that housing as a pure financial asset ('predatory equity'). Later work with Uffer (2016) reveals a similar process in Berlin, where state-owned public housing has been the target of 'predatory' acquisition by private equity firms. Their research found that financialization was a key driver of urban division, producing "heightened inequality and often worsened housing conditions" (Fields \& Uffer 2016: 1497), driven by cost-cutting, short-term 'assetising' strategies, and fluctuations in the global financial ecosystem with which the homes were now increasingly co-dependent.

In diverse ways, these studies engage with the role of the state in the financialization of housing, and echo the findings of Christophers (2016) in his historical analysis of the UK state's treatment of its land. Engaging with Harvey's (1999) axiom that under capitalist relations land will be increasingly treated "as a pure financial asset", Christophers focuses his attention specifically on the role of the state in financializing land - a role that "has to date been afforded very limited theoretical or empirical attention" (2016: 1). Ultimately, whilst recognising the "far from straightforward or unambiguous" nature of the UK case, Christophers concludes that the state plays a crucial enabling role in indirectly financializing land in the UK through aggressive privatisation. The UK's public estate has been financialized not by the state itself, but as the state has sold public land to private actors. Similarly, in New York, Fields found that the state, through its partial dismantling of rent regulation and privatising of public assets over several years, indirectly provided "crucial assistance" to the financializing agent, releasing stock for financial capital to acquire (Fields 2013: 192). Echoing our

\footnotetext{
${ }^{1}$ It is important to note that the commercialisation of some UK Housing Associations is not a process which can be entirely attributed to their post-GFC financialisation, but is rather a sectoral shift which has been underway for some time. Indeed, by 2016 the shift was such that one major London Housing Association announced it was to abandon its core business of providing affordable housing for low income groups completely, to focus on the private market house building only.
} 
above discussion on urban entrepreneurialism and financialized governance, Fields found that these decisions were made in a context of unequal hierarchies of state power, with cuts to federal funding for cities driving municipal government to more 'economic' approaches to public assets. To use Christophers' framing, the state was not the executor of financialization per se but rather the facilitator or enabler of financialization, carried out by other actors. The state sells, transfers, or facilitates the transfer of land, previously privileged for its use value, to private actors who then treat it as a purely financial asset, interested only in the rent it can yield. This pattern is echoed in Berlin, where public housing corporations were disposed of by the state and acquired by financializing agents who privilege only its exchange value (Fields and Uffer, 2016). This pattern also holds for Aalbers and colleagues (2017) and Wainwright and Manville's (forthcoming) work on UK and Dutch HAs. The prospects for financialization - engaging capital markets for development capital, and the expansion of financial products on balance sheets - grew as the ties between housing associations and the state were loosened, and "reduced state funding... led social housing providers to become more reliant on capital market intermediaries" (Wainwright and Manville, forthcoming: 1). Aalbers (2017) therefore links the incipient financialisation of public/social housing to the withdrawal of state funding, on the one hand, and the abdication of state responsibility on the other; this retraction and mutation of the role of the state indirectly produces financialisation in non-state providers. While, generally speaking, this direct/indirect dichotomy might oversimplify the complex role the state plays in these examples of housing financialization, these studies point towards a minimal, hands-off role for the state in financialization, in contrast to the financialized municipalism entrepreneurialism emergent in London, in which the state is the active executor of financialization.

It is becoming increasingly clear that the historical status of non-market housing types - homes which are vital in giving those on low-incomes a claim on urban space - affords no necessary protection against their incorporation into the accumulation strategies of financial capital (Fields 2017). However, as yet there is little understanding of how such financialized recommodification plays out when the housing in question is (and continues to be) non-market for users - that is to say, when public housing becomes a financial asset. So far, the implications of the imposition of this dual nature on public housing are unknown. On the one hand, at the point of consumption, the housing exists as an affordable, non-market tenure. On the other hand, the same public housing also functions as a globally traded financial product. In what follows we unpick this contradictory, Janus-faced character and the new mode of entrepreneurial governance it undergirds.

\section{Financialized municipal entrepreneurialism in action: Council-led property speculation in London}

The London Borough of Lambeth is a Labour-controlled Local Authority in Inner London, with a population of 318,216 (2014). It is a long, narrow borough, widening from the Waterloo/South Bank area south of the river Thames in central London, through dense, inner-city neighbourhoods, to quieter suburbs 7 miles south of the river. Much of Lambeth has experienced intense gentrification over the last 25 years. Despite heavy 'territorial stigmatisation' of many neighbourhoods in the borough, decades of neglect and capital flight is being reversed. Investment is rapidly returning to the area, pushing up the price of housing and resulting in strong displacement pressures. In the face of these pressures, much of Lambeth retains comparatively high levels of social housing, some of which is now being regenerated through Homes for Lambeth $(\mathrm{HfL})$, Lambeth Council's SPV.

The empirical data presented here was collected between 2015 and 2016, and comprises a combination of 10 semi-structured interviews with key actors, alongside a close analysis of all relevant secondary sources produced by the Council, activist groups, central government, and other actors. Interviewees included a senior elected Councillor (Lambeth Councillor) and a Senior Council Officer (Lambeth Officer) with close knowledge of the project, community activists campaigning against 
estate regeneration, and Councillors and Officers in other London boroughs who have set up housing SPVs. Additionally, a catalogue of secondary data from all relevant and publicly available Lambeth Council documents was acquired, in combination with web searches to acquire relevant grey literature relating to the setting up of SPVs.

The decision to set up HfL can be traced back to October 2012 when Lambeth Council embarked on a significant regeneration plan to finance the refurbishment of their existing housing stock (Lambeth Council, 2012). In response to central government budget cuts, and a decision made locally to upgrade existing homes to a 'Lambeth Housing Standard', set higher than the legislative minimum, the council announced it had a $f 59 \mathrm{~m}$ funding shortfall to refurbish homes. Their response was to pursue a programme of council estate regeneration predicated, in part, on the demolition of six council estates and their redevelopment under an SPV at higher densities and with the crosssubsidisation of affordable homes by new private builds. Residents of estates slated for demolition contested the council's structural surveys and highlighted discrepancies in their financials. By 2014 the rationale for regeneration came to focus on the need to address the housing crisis in Lambeth; the development of 1,000 council homes became a key manifesto pledge in that year's borough elections (Lambeth Labour, 2014). Like every other London Borough, Lambeth faces what is almost universally recognised as a 'housing crisis' (Shelter/KPMG, 2015; Edwards, 2015). The precise nature and causes of this crisis are beyond the scope of this paper (see Watt \& Minton, 2016), but it is predominantly a crisis manifested in a vast structural discrepancy between a high and growing demand for decent, affordable housing in the city, and the diminishing availability of such stock, resulting from almost four decades of the neglect and neoliberalisation of housing policy.

In this context, Lambeth decided to "intervene in the market" in response to its "failure" to "deliver affordable housing" (Lambeth Officer), by creating HfL, a housing and regeneration SPV. An SPV, (or Special Purpose Entity) is an 'off balance sheet' limited company, created by a parent company to pursue a specific project or interest. According to PricewaterhouseCoopers, SPVs play a "vital role in the efficient operation of global financial markets" (2011: 2), enabling the parent company - "typically a major investment bank or insurance company" (ibid: 4) - to fulfil a temporary or narrowly specific objective. The SPV is usually set up as a so-called 'orphan company', which means that it is legally independent from the parent company, often isolating them from any financial risk and enabling access to credit on preferential terms.

SPVs have emerged in recent years as a preferred option for local authority housing and regeneration in London and the UK, with a third of local authorities in England developing or having developed SPVs in recent years. SPVs open up flexible governance spaces within which Councils can operate with increased autonomy from centrally-imposed regulations and restrictions. SPVs are being created to enable a Council to: act commercially and speculatively to build private market housing for sale, which cannot be done within the council's housing budget; circumvent borrowing restrictions and access new sources of funding, including from institutional investors; transfer existing council housing and tenants from their well-protected status under statute to a more precarious status constructed by the SPV; and avoid right to buy legislation. Significantly, SPVs cannot build, provide, or manage council housing and as such any homes transferred to or built by an SPV will be of a more insecure tenure status; homes held by the SPV are not strictly speaking public or social housing in that sense. The rents can be set by the SPV at their discretion.

Lambeth's SPV - described as a "wholly-owned council company" (Lambeth Council, 2014) is in fact a complex, multi-company, corporate entity, with intricate public-private form, designed "to harness the full economic potential of the local property market for the benefit of Lambeth's residents" (ibid: 13). HfL enables Lambeth Council to "act as a commercial property developer" (ibid: 13), developing private houses for rent and sale and, mirroring private sector developers, cross-subsidising the provision of affordable homes, to the extent it is deemed commercially viable. In the context of a 
local property market with values more than double the national average, the Council is using its land assets (its housing estates) as financial assets, pursuing a profit making, self-financing regeneration strategy. This quasi-financialized attitude to the estates is confirmed by the acknowledgement of the importance of "high-value regeneration areas" (estates in desirable parts of Lambeth) to the approach, as they present opportunities to "generate long-term returns for the council", whose personnel are fortified by the attitude of "where we own land, we should be looking to invest our capital" (Lambeth Officer).

Structurally, HfL comprises a top-company, wholly-owned by the Council, with at least three subsidiary companies, of varying public-private form (See Figure 1). The redevelopment of the estates will be undertaken by the wholly-owned top company ( $\mathrm{HfL}$ ), and this will produce four different tenures of homes: homes for private sale; homes for private rent; intermediate ('shared ownership') homes; and 'affordable homes', set at 'council-rent levels'. The new private flats will then be sold to a wholly-owned, for-profit subsidiary for higher than build costs, which will cross-subsidise the sale of replacement affordable housing to a wholly-owned subsidiary not-for-profit HA for less than build costs. There is also a subsidiary Joint Venture, with an institutional investor, in which $\mathrm{HfL}$ will be a minority shareholder. The Joint Venture will hold the new affordable homes, and the desired partner is a Pension Fund.

The homes and land which comprise the estates will be transferred to the SPV on a 30-60 year lease, a quasi-privatisation which removes the existing and future homes from statutory public housing regulations and transfers landlord status from the Council to $\mathrm{HfL}$ and a pension fund. As such, the SPV removes all existing and future homes from the Council's ring-fenced, capped, and regulated Housing Fund, which would otherwise limit how much, and from whom, the Council could borrow. Financing the project in this SPV-created liberated space enables $\mathrm{HfL}$ "to borrow from different sources that the council... couldn't have otherwise borrowed from" (Lambeth Officer). Commercial housing developers and HAs (the traditional PPP partners) are being avoided (Lambeth Officer and Councillor), and instead partnership and funding is being sourced from financial sector actors, through novel forms of debt and equity (the Joint Venture), ranging across traditional loans, partial ownership, and the sale of rental streams over extended (30-60 year) contracts. 


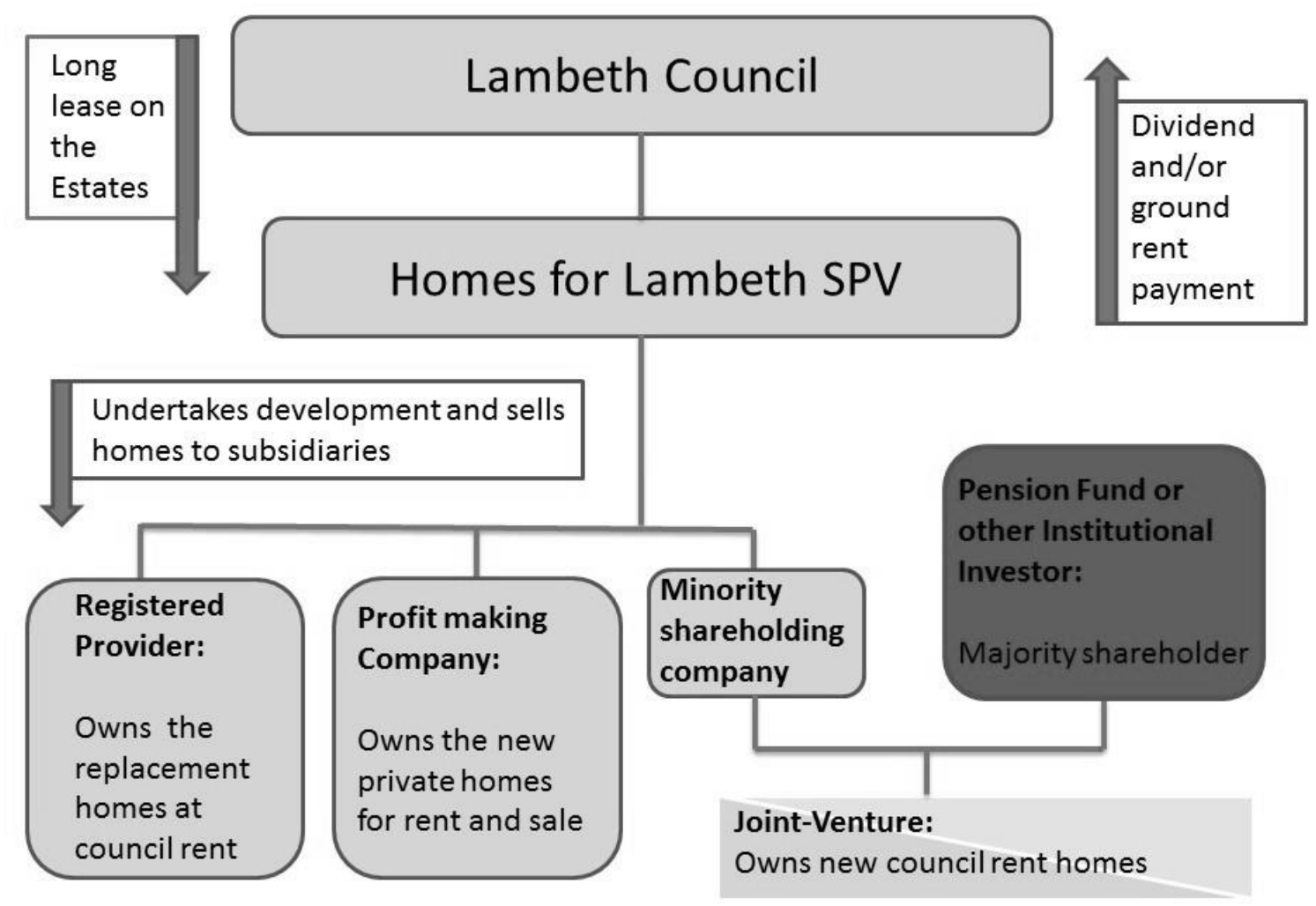

Figure 1: The Structure of Homes for Lambeth and its Subsidiaries. Source: Authors.

\section{Towards an interventionist and financialized urban entrepreneurialism}

Lambeth Council position their use of financial practices and institutions, and their move to intervene more directly in the market as a private developer, as a unique innovation. Yet, whilst this is true with regards to the precise configuration of $\mathrm{HfL}$, the turn towards SPVs is novel, but not unique. More than an isolated or experimental outlier, $\mathrm{HfL}$ reflects wider transformations in local governance across London, pointing to an emergent variant of interventionist and financialized municipal entrepreneurialism. Housing SPVs have been set up in over half of London's boroughs (see Figure 2), as urban statecraft and housing delivery are reconfigured in tandem at the nexus of 'austerity urbanism', 'late-entrepreneurialism', and 'financialization' (Peck 2016).

\begin{tabular}{|c|c|c|}
\hline $\begin{array}{l}\text { LOCAL } \\
\text { AUTHORITY/SPV }\end{array}$ & $\begin{array}{l}\text { HOMES TO } \\
\text { BE } \\
\text { DELIVERED }\end{array}$ & DESCRIPTION \\
\hline $\begin{array}{l}\text { Barking and } \\
\text { Dagenham / } \\
\text { Reside and Be } \\
\text { First }\end{array}$ & 42,000 & $\begin{array}{l}\text { Reside is a wholly-owned council SPV which regenerates public housing } \\
\text { estates on an 'Income Strip' model. Public estates are cleared of buildings } \\
\text { and tenants, and sold to a private investment fund, in this instance Long } \\
\text { Harbour, on a long lease ( } 40 \text { years). The receipts for this sale provide the } \\
\text { capital funding for the regeneration, and the council has control over } \\
\text { managing the regeneration and the properties. The council pays an } \\
\text { indexed rental stream to Long Harbour for the duration of the lease, after } \\
\text { which the land reverts to the council. The homes produced are not secure } \\
\text { 'council homes' as they are held by the SPV. Initial developments were } \\
\text { entirely sub market rent, however market homes are now being } \\
\text { produced. }\end{array}$ \\
\hline
\end{tabular}




\begin{tabular}{|c|c|c|}
\hline & & $\begin{array}{l}\text { In } 2016 \text { the council decided to transfer its entire regeneration department } \\
\text { to another profit-making SPV, BeFirst, which will pursue similar } \\
\text { financialized regeneration projects. The council is now actively buying land } \\
\text { in addition to using public land. }\end{array}$ \\
\hline $\begin{array}{l}\text { Newham / Red } \\
\text { Door Ventures }\end{array}$ & 3000 & $\begin{array}{l}\text { Red Door Ventures is a wholly-owned council SPV which develops } \\
\text { primarily private rental housing, in order to generate "long run returns... } \\
\text { in light of very significant reductions in Government grant funding" } \\
\text { (Newham Council 2015: 6). Spurred by a desire to directly "exploit the } \\
\text { borough's own land assets commercially" (The Guardian 2015), the } \\
\text { council sells land, often previously occupied by public housing estates to } \\
\text { the SPV, which acts "in the same manner as any other private sector } \\
\text { [property] company" (Newham Council 2015: 2). The SPV only builds } \\
\text { affordable houses when needed to "comply with planning requirements" } \\
\text { (ibid: } 3 \text { ), and they are let at the highest rents possible within the planning } \\
\text { requirements. The homes produced "will not be Council housing" and "are } \\
\text { not intended for households towards whom the Council owes a housing } \\
\text { duty" (ibid: 4). The SPV has been funded through commercial rate loans } \\
\text { of f162 million from the council, which will generate a profit. It is hoped } \\
\text { that the council can sell equity in the SPV to a financial sector partner, } \\
\text { once it holds a "desirable" number of homes (ibid: 5). }\end{array}$ \\
\hline Other examples & \multicolumn{2}{|c|}{$\begin{array}{l}\text { Housing SPVs have also been established, or are being set up in: Barnet, Camden, } \\
\text { Croydon, Ealing, Enfield, Greenwich, Hammersmith and Fulham, Haringey, Havering, } \\
\text { Hounslow, Kensington and Chelsea, Lambeth, Merton, Redbridge, Southwark, Sutton, } \\
\text { Waltham Forest. }\end{array}$} \\
\hline
\end{tabular}

Figure 2: Council SPVs in London. Source: the authors, based on independent research.

Speaking in interview, the Lambeth Officer captured something of the unfolding nature of this conjunctural transformation. When asked about the challenges local authorities face in providing affordable housing, he articulated the rationale for setting up $\mathrm{HfL}$ by echoing the decline and failure of two prominent modes of urban governance: the Keynesian model of urban managerialism; and the state-facilitated, market-led model of urban entrepreneurialism through which local government has sought to skim some benefit off speculative private sector developments:

"... the fundamental problem is that social rent housing doesn't work financially... you are either relying purely on government subsidy, which has pretty much gone, or subsidy from a developer, crosssubsidising it. But because of the legislative framework within which we are working, developers don't do that anymore. so you very rarely see anyone deliver that very subsidised housing" (Lambeth Officer).

Almost axiomatically, $\mathrm{HfL}$ was conceived of in a context of a decline in national investment for local public services, including social housing provision, funded by national taxation. This context of course is not new: the decline of this mode of governance has been remarked upon since the 1980s, although it has been driven to new extremes across local government functions in the contemporary era of 'austerity urbanism'. Since 2010, unprecedented budget cuts to local revenue and capital budgets, have predicated the financial future of local government - as well as a whole host of public goods provided at this scale - on the ability of local authorities to generate their own sources of income.

At the same time, $\mathrm{HfL}$ also represents an attempt to move away from the facilitative and minimal modes of entrepreneurial statecraft that replaced Keynesian managerialism in housing. HfL is developing in parallel to, but also very much out of the perceived failures in, the minimal state/planning gain approach, whereby since 1990 the majority of non-market housing in England has been realised through a tax on private developments. In part, these failures pertain to the inadequate amount of genuinely affordable housing delivered through such mechanisms, as developers have proven increasingly adept at using (and manipulating) viability tests to reduce the ratio of non-market 
to market units (Colenutt et al. 2015) and as central government has removed any requirements on developers to deliver social housing on their sites (Housing \& Planning Act 2016). Similarly, HfL represents a move away from the allied models of regeneration associated with this ideologically minimal and facilitative form of municipal entrepreneurialism, and exemplified by Private Finance Initiatives (PFIs) (Hodkinson \& Essen 2015). The PFI, was a mechanism widely used to deliver housing regeneration, which relinquished control over project delivery, design and asset management to private sector partners, with the state paying a long term charge for the services. In this mode of governance, private sector provision was exalted as efficient in ways the public sector could never be (Froud 2003) and the state's role was limited to strategic oversight.

$\mathrm{HfL}$ signals a departure from this minimal role for the local state. Local Councils are once again acting as house builders, something which has been all but absent since the neoliberalisation of UK housing policy. Lambeth Council is taking on a directly interventionist role, avoiding partnering with commercial property developers or HAs, as in the earlier forms of entrepreneurial governance, in order to have more control over new developments and capture more of their value, which is typically lost to private actors:

"The proposed special purpose vehicle (SPV) would enable the council to...reinvest surpluses for the benefit of local people. Under normal circumstances, the 15-20\% development profit would go to private developers" (Lambeth 2015b)

Positioned unfavourably in unequal scalar-state relations, constraining where and how they can raise or generate funds, local authorities - as much by dull compulsion as ideological zeal - are increasingly looking to the land they own and are leaning towards ambitious and speculative regeneration-led initiatives on their estates as "one of the few areas in the council that can actually generate income" (Lambeth Officer). However, instead of facilitating the private sector to undertake these activities, they are doing it themselves. The creation of SPVs to construct mixed-tenure developments with privatised funding, including through institutional investors, is one example of this. In HfL Lambeth Council believe they have a viable long-term solution to their housing and fiscal crises:

"[HfL] has basically got two key objectives; one is to deliver as much affordable housing as possible, but the other is to generate long-term revenue streams... that would then travel back up to the council, to fund services."

The commonly shared pressures behind Lambeth's move towards more explicitly interventionist forms of municipal statecraft are leading to a more active role for the local state, albeit in narrowly entrepreneurial and increasingly speculative and financialized ways, across London. Indeed, although still in its formative stage, it is possible to discern from $\mathrm{HfL}$ the signs of an emerging urban governance logic, that is being replicated across the capital: "All councils are wanting to do these SPVs now because they are profit generating..." (Estate resident). Using the case of $\mathrm{HfL}$ as an indicative exemplar, whilst recognising that the specifics of each SPV varies, a broad-brush picture of this interventionist and financialized variant of municipal entrepreneurialism can be sketched provisionally across the following four points.

First, $\mathrm{HfL}$ represents a noticeable shift away from the entrepreneurial logics described above. Documentation outlining HfL makes frequent reference to 'control', 'influence', and council power. In a way reminiscent of favourable perceptions of urban managerialism, public sector decision making and intervention is exalted; London Councils are once again building houses on a relatively significant scale. The fact that HfL is a 'wholly-owned company' has always been the primary justification for its establishment over other tried-and-tested regeneration strategies (Lambeth 2015b; Lambeth 2015a). This however, does not signal a simple return to, or revalorisation of, the public sector ethos or modus 
operandi. Indeed, whilst HfL and other council-owned SPVs make much out of their publically owned status, their core operating logics and practices have been borrowed from the private and financial sector: they function as commercially-minded, speculative, and risk-taking real-estate ventures.

Secondly, HfL represents an aggressively commercial and speculative mode of governance new to local government in the UK context. Whilst set up as 'wholly-owned council companies', often with the express aim of building more housing at affordable rent levels, SPVs enable councils to act as commercial property developers and speculators, effectively "converting council housing into a profit making machine" (Estate resident). Taken outside of Council restrictions, any profits accrued through these SPVs can be released to the local authorities and used to finance a whole range of Council services. Further blurring public-private distinctions, SPVs such as $\mathrm{HfL}$ ape the viability-led business models of private-sector housing developers. Market housing cross-subsidises the development of affordable units. This means that the development of affordable housing is predicated on the speculative development of private housing, and what once may have been seen as a primarily social and political issue has, to an even greater extent, become first and foremost an economic issue.

Thirdly, $\mathrm{HfL}$ is predicated on treating public land as a financial asset. Housing and regeneration SPVs reflect and actively reproduce a model of market-led regeneration based on land-value uplift, or treating public land as a financial asset. The business-cases for a number of SPVs across London actively seek to make use of high value public land, including existing council estates in expensive locations. The model incorporates an attitude to land which sees it as a financial resource to be put to 'highest and best (economic) use', over and above any consideration of it as a site of broader public policy delivery. The Government's Estate Regeneration National Strategy articulates this emerging tendency, effectively advocating the adoption of a new way of seeing in estate regeneration (Government 2016), outling a pressing "need" for "local authorities to view estates as long-term, income generating assets" (DCLG, 2016: 11). There has thus been a shift in how estates are viewed, from an optic of moral, social, and public policy priorities, to a commercial, financial agenda focussed on "'asset management', valuations and risk modelling" (Wainwright \& Manville, forthcoming: 6).

Finally, $\mathrm{HfL}$ positions the local state as the executor of financialization. This way of operating sits in contrast to the findings of Christophers (2016), echoed by other housing financialization researchers, who depicts the role of the state vis-a-vis financialization as facilitative: "if the UK state has indeed increasingly come to financialize public land, it has for the most part done so only indirectly" and instead of treating the land "as a financial asset per se by developing, letting, trading, actively speculating with, or otherwise directly exploiting it", the state has enabled such a treatment of its land by "strategically selling" it "to actors that do treat land in such a way" (Christophers 2016: 2). Homes for Lambeth is markedly different to this. Rather than indirectly financializing public land through aggressive privatisation and deregulation, the local state in this instance has partially retained its interest in its land assets, and is itself treating them akin to a financial asset. The state in this case is the financialiser, privileging land for its exchange value.

At one level HfL represents a new policy model and governance fix, enabling Lambeth Council to pursue its public policy objectives - addressing a housing and fiscal crisis - in a directly interventionist way, employing the techniques and resources of financial capital to circumvent nationally imposed budgetary and regulatory constraints and to become a major housing developer again. At another level, $\mathrm{HfL}$ also signals the active constitution by the local state of public housing estates as quasi-financial assets and former council homes, and the rents they yield, as new opportunities for institutional investment and value extraction. This dynamic, as the next section explores, brings with it a set of risks and tensions, some of which contradict the Council's stated aim to maintain control over new developments and which set the stage for a loss in public control through full-scale privatisation and financialization. 


\title{
5. Social, Economic, and Political Consequences of the Financialization of Public Housing
}

The success of the $\mathrm{HfL}$ model of public housing regeneration is predicated on the constitution of novel linkages between state owned affordable housing and financial capital. HfL, and the SPV model more generally, enables public housing to be remade as an asset class, alike in many respects to public infrastructure and capable of absorbing substantial portions of the global pool of liquid assets - the 'wall of money' (Fernandez \& Aalbers, 2016) - seeking stable, secure real estate investments in a postcrisis investment landscape. Unlike other types of rental housing financializations (Fields 2013, 2017; Fields and Uffer, 2016), public housing is emerging as an attractive investment characterised by its low risk profile and reliable underwriter (the state), and as such is akin to infrastucture.

The financialization of infrastructure is at a "matured" stage(O'Neill, 2015, p.4; cf. Ashton et al. 2016; Torrance 2008)).. While large capital projects have always relied on private finance, public infrastructure itself has now become a financial asset, with the attendant elevation of motives, imperatives and metrics - from the "world of private finance and financial markets" - above other "economic and social goals of the day" (O'Neill, 2015, p.4). The relevance of this to the present case is that, in a manner perhaps not applicable to other tenures, public housing is being treated as an infrastructural investment by financial capital. Infrastructure leases are attractive to investors as they generate stable returns over long periods, occupy often monopolistic positions in the market, and deliver typically recession-proof and inelastic revenue streams ( $O^{\prime} N e i l l 2009$ ). These characteristics make their revenue streams highly amenable to financial engineering, and offer innovative means to extract and trade value through opaque financial instruments. Public housing, in an booming housing market like London, exhibits all of these characteristics: its rents and covenants are governed by state policy; the state is its ultimate owner and underwrites rent, providing durability and stability; and demand is far greater than supply. As such, HfL represents a clear opportunity for investors:

\begin{abstract}
"pension funds... are sitting on billions and billions of pounds that they want to put into stable low risk investment - they can't put into banks because interest rates are low, can't put it on the stock market because that's risky, can't put it into government debt because they don't look quite as stable as they used to. Social rent is low, affordable, people will always pay it, and it is underwritten by the state through housing benefit" (Lambeth Councillor).
\end{abstract}

Financial sector involvement in $\mathrm{HfL}$ will come in the form of traditional loans, partial ownership, and the sale of rental streams over extended (30-60 year) contracts. Unlike traditional forms of debt funding, in which loans can be repaid through incomes (rents), this latter approach involves the effective sale of the income stream (the rental payments), backed up by the 'security' of the leasehold or freehold on the property itself, in return for an up-front lump sum: "Let's say [HfL] will construct 100 properties, and that would generate an income stream of $£ X$ million, [institutional investors will then] purchase that income stream for the next 30 years, so that will then pay back the construction costs" (Lambeth Officer). 'Soft-market testing' has been undertaken to gauge the interest of institutional investors in this novel source of funding for council-built housing. ${ }^{2}$ On the one hand, it provides a means for councils to access large-scale upfront funding for new development, and on the other, it creates a financial asset out of public housing, which can be bought and sold on secondary markets by financial institutions with the manner and ease of other similar assets. The homes

\footnotetext{
${ }^{2}$ This form of public housing funding is already in existence in a similar format in at least one other London borough.
} 
produced under this novel form of financialized public housing development appear to acquire a dual character not currently found in public housing in the UK. In one respect, they will have primacy of use value: non-market houses preserved for those deemed 'most in need', and with rents set not by the market, but by the SPV. In another respect, they will constitute a class of financial asset, with use value only in the rents they yield, to be bought and sold in the dislocated non-place of global investment markets, absorbed by a wall of money interested only in their exchange value.

This seemingly contradictory character - of interventionist state public policy and financialized extraction, of use value and exchange value - creates tensions and complexities as well as a constellation of risk and uncertainty not yet seen in the UK's public housing sector. Born to some extent of necessity, the council is engaging in intricate, far-reaching, and so-far unknown financial and corporate entrepreneurialism to deliver public policy objectives. However, the scale of the tensions and contradictions which are revealed on analysis suggest that those policy objectives risk being subverted, forgotten, and/or severely diluted by the complexity and financialized motivations necessitated by the project. Some of the foreseeable risks, tensions, and contradictions - social, political and economic - include: a reworking of the obligations to tenants, citizenry, and investors; an imbalanced public/private risk profile; the future disposal of assets; and deferred democracy.

Under the terms of the new relationship, $\mathrm{HfL}$ will need to maintain the rental stream or risk losing the underlying asset, the homes. This constitutes a critical pressure, one which may require Lambeth to "re-orient a broad range of state activities" to maintain the value flow (Ashton et al. 2016: 1385), with this taking priority over other responsibilities the council bears. The exalted notion of control is contrasted here with an obscuring of accountability, wherein $\mathrm{HfL}$ acquires obligations not just to tenants, or the local citizenry, but to global financial interests. The new affordable homes created by the SPV will no longer be protected by state regulation and can be switched to private market rates as tenants change. Therefore, over the lifetime of the contract such countervailing pressures, and the calculative, value-generation driven logics which they necessitate (Wainwright \& Manville Forthcoming), may bring into question the affordability of rents, or undermine the public policy objective to adequately house those on low-incomes and the vulnerable. Under the terms of the new relationship, these consequences, and the full implications of the financialization of Lambeth's public housing, will likely not be felt in the near future, but will stretch out across a longer temporality, produced and reproduced by the interplay between the 'governance in motion' that such intensified and extended integration between public goods and the financial sector requires (Ashton et al. 2016), and the evolving need to see public housing as a "long-term, income generating asset" (DCLG 2016: 11).

The muddying of democratic and financial accountability is further complicated by the political and economic risk which exists over the lifetime of the contract. The impossibility of foresight regarding economic and central government policy changes - on public housing and rents, on public assets - posed one of the primary obstacles to the establishment of the $\mathrm{HfL}$ project. As acknowledged by a Lambeth Councillor, such risks pose a 'serious' threat to the local authority and HfL:

"we can't confidently say that the Govt won't continue to cut rent, won't extend the Right to Buy, won't outlaw SPVs. [It] makes it politically difficult because we can't promise that this won't happen. To which my response has been: we can't promise, but we also can't sit around and do nothing because we are scared" (Lambeth Councillor).

Such risks pose a clear threat to the ability to maintain the income stream, as rental assets could be lost, or degraded. Investors have told the council that they "have to bear those risks" (Lambeth 
Officer). These risks, weighted firmly to the disadvantage of the council, and ultimately against present and aspiring tenants of the affordable homes, exert new pressures on the ability of the council to meet its original affordable housing policy objectives. The management of this risk profile is likely to become a crucial question of local democracy, as instances of governance-by-SPV multiply in the UK. ${ }^{3}$

If $\mathrm{HfL}$ does not grow at the speed and volume implied by the council's aspirations, or should HfL encounter the risks highlighted, it could become a serious financial burden. The speculative model of public house production, based on land-value uplift, carries with it deep economic risks in an overheated property market like London. In such circumstances, the risk of a wholesale disposal of $\mathrm{HfL}$ and its tenants, already transferred outside the council to a private company in the creation of the SPV, may loom large:

"[They'll] sell the equity, because they will need the cash. So they will sell some of the company, and then the council will own $70 \%$ and the investors 30\%, and then that could slide. Councillors don't have that long-term perspective, they have the four-year perspective - 'let's sell some equity-off so that we can fix all of the potholes now" (Estate Resident).

In any number of political or economic circumstances the council could dispose of the homes held by $\mathrm{HfL}$, or even $\mathrm{HfL}$ itself ${ }^{4}$, opening up a portal for further rounds of financialization and the entry of Global Corporate Landlords into the borough (Beswick et al, 2016). The uncertainty and risk here lies squarely with the tenants, and those in need of affordable housing.

The possibility of Lambeth disposing of the assets also illustrates how starkly the interests of $\mathrm{HfL}$, and the interests of Lambeth Council, may diverge, and how the public policy objectives of the council, and the private interests of $\mathrm{HfL}$, may conflict. In transferring the land to the SPV, the council is deferring control of the homes and land it controls to a non-public body. Local democratic structures, and through them local people, will no longer retain full control over public assets. The boards of $\mathrm{HfL}$ and its subsidiary companies will be primarily comprised of councillors and officers, however in these roles the councillors and officers will be required to adopt the legal duties of Directors of a private company, and not of public servants. Governance-by-SPV carries a scope for conflict of interest which, in the words of the officer responsible for the project, is "massive", and managing this will be one of the central features of the project. The complexity of negotiating the risk entailed by this deep entanglement of corporate and public interests is characteristic of the $\mathrm{HfL}$ project as a whole, one in which democracy is deferred to a speculative private entity, and public policy objectives are reduced to questions of financialized economic viability.

\section{Conclusion}

This paper has sketched an outline of an emerging form of municipal entrepreneurialism, through the use of council owned SPVs in London. The empirical case study presented in this paper demonstrates the interventionist role taken by the local state in building housing, by financializing its own statecraft and public housing stock. By employing the tools of the financial sector, viewing its land as a financial asset, and creating innovative portals for financial capital to access public housing, Lambeth has constituted its public housing stock as a proto-asset class for global institutional investors. The paper

\footnotetext{
${ }^{3}$ In early 2017 central government announced its intention to extend the 'right to buy' to council owned SPVs.

${ }^{4}$ The council have acknowledged the significance of this risk, and have introduced a 'triple lock', in which the sell-off of the properties would require the approval of the board of $H f L$ the full cabinet and two thirds of the council. However, as the personnel of these bodies will be exceptionally similar, a Senior Lambeth Officer acknowledge that opponents of the project "think that it is too loose, and you can kind of see why".
} 
has provided further evidence of the expansion and permeation of financial practices and investment into housing generally - confirming rental housing as a "an important new node for financializing projects globally" - and non-market housing specifically as a "frontier for financialization" (Fields, 2017). The specific quality of the housing in question in this paper has revealed new dynamics that provide an important addition to the growing knowledge of the financialization of rental housing. Whereas the work of Aalbers (2016), Wainright (2017), Fields $(2015,2017)$ and Fields and Uffer (2016) demonstrates the close interconnection of privatisation and financialization - 'financialized privatisation' - the case study presented here points to a more ambiguous form of partial-privatisation akin to infrastructural financialization, giving the new affordable housing produced by HfL a Janusfaced quality, functioning both as globally tradeable asset and decommodified home.

More than an isolated innovation or experiment in financialization, $\mathrm{HfL}$ is representative of a broader shift in governing logics at the local scale across London, towards what has been termed in this paper Financialized Municipal Entrepreneurialism. This mode of governance has been analysed conjuncturally, emerging out of the decline of urban managerialism, entrenched in the present austerian context, and the perceived failure of minimalist and facilitative modes of urban entrepreneurialism - such as the planning gain approach or PFI. We have shown that local authorities in London are seeking to play a more interventionist role in public policy areas in which they recently provided only oversight, and are turning to financial practices and institutions as urban governance fixes, opening up smoother governance spaces (through SPVS) and new lines of equity and finance (through institutional investors). In this way, local authorities, have sought to circumvent the political and fiscal constraints imposed on them by central government, and believe they have found a path towards greater local capacity and control, as well as financial self-sufficiency.

In the final section of this paper, however, we suggested how this may represent a pyrrhic victory, especially for existing and future tenants of the quasi-public affordable homes created through HfL. The gains in capacity and control in the short-term, look likely to unravel in the longterm. As new forms of governance-in-motion, the SPV-driven pursuit of public policy splits local authority accountability, imposes long-term and potentially unforeseen risks on councils, and renders formerly secure council estates and tenancies inherently insecure. As residents of the Estates have emphasised on countless occasions, there is nothing - beyond the word and goodwill of Lambeth Council - to stop the partial or complete sale of $\mathrm{HfL}$ to private actors, including Global Corporate Landlords, portending another escalation of the linkages between financial capital and (ex-)public housing, and a new round of financialized value extraction and appropriation.

\section{References}

Aalbers, M. (2012) Subprime cities: the political economy of mortgage markets, Wiley-Blackwell. Aalbers, M. (2016) The Financialization of Housing: A political economy approach., Taylor and Francis.

Aalbers, M. (2017) The Variegated Financialization of Housing: Symposium for IJURR.

Aalbers, M.B., J. van Loon and R. Fernandez (2017) The financialization of a social housing provider.

In The Variegated Financialization of Housing: Symposium for IJURR

Housing \& Planning Act. (2016) Housing and Planning Act 2016, Available at: http://www.legislation.gov.uk/ukpga/2016/22/contents/enacted.

Ashton, P., Doussard, M. \& Weber, R. (2016) Reconstituting the state: City powers and exposures in Chicago' s infrastructure leases. Urban Studies, 53(7), pp.1-17.

Barnekov, T.K., Boyle, R. \& Rich, D. (1989) Privatism and Urban Policy in Britain and the United States, Oxford: Oxford University Press.

Christophers, B. (2016) The State and Financialization of Public Land in the United Kingdom. 
Antipode, 0(0), pp.1-24.

Cochrane, A. (2007) Understanding Urban Policy: A Critical Approach, Oxford: Blackwell Publishing.

Colenutt, B., Cochrane, A. \& Field, M. (2015) The rise and rise of viability assessment. Town and Country Planning, 84(10), pp.453-458.

Davidson, M. \& Iveson, K. (2015) Recovering the politics of the city: From the "post-political city" to a "method of equality" for critical urban geography. Progress in Human Geography, 39(5), pp.543-559.

Davidson, M. \& Ward, K. (2014) Picking up the pieces': Austerity urbanism, california and fiscal crisis. Cambridge Journal of Regions, Economy and Society, 7(1), pp.81-97.

Davis, C. (2013) Finance for Housing: An Introduction, Bristol: Policy Press.

Davis, GF. (2009) Managed by the Markets: How Finance Re-Shaped America. Oxford University Press, Oxford.

DeFilippis, J. (2004) Unmaking Goliath: Community Control in the face of Global Capital, New York City: Routledge.

Farmer, S. (2011) Uneven public transportation development in neoliberalizing Chicago, USA. Environment and Planning A, 43(5), pp.1154-1172.

Featherstone, D. et al. (2012) Progressive localism and the construction of political alternatives. Transactions of the Institute of British Geographers, 37(2), pp.177-182.

Fernandez, R., \& Aalbers, M. B. (2016). Financialization and housing: Between globalization and Varieties of Capitalism. Competition \& Change, 20(2), 71-88

Fields, D. (2017) Unwilling Subjects of Financialization. International Journal of Urban and Regional Research.

Fields, D. \& Uffer, S. (2016) The financialization of rental housing: A comparative analysis of New York City and Berlin. Urban Studies, 53(7), pp.1486-1502.

Fields, D. (2013) From property abandonment to predatory equity: Writings on financialization and urban space in New York City. City University of New York.

Fox-Gotham, K. (2009) Creating Liquidity out of Spatial Fixity: The Secondary Circuit of Capital and the Subprime Mortgage Crisis. International Journal of Urban and Regional Research, 33(2), pp.355-371.

Froud, J. (2003) The Private Finance Initiative: risk, uncertainty and the state. Accounting, Organizations and Society, 28(6), pp.567-589.

Gotham, K.F. (2013) Dilemmas of Disaster Zones: Tax Incentives and Business Reinvestment in the Gulf Coast after Hurricanes Katrina and Rita. City \& Community, 12(4), pp.291-308.

Gotham, K.F. (2016) Re-anchoring capital in disaster-devastated spaces: Financialization and the Gulf Opportunity (GO) Zone programme. Urban Studies, 53(7), pp.1362-1383.

DCLG. (2016) Estate Regeneration National Strategy: Finance and Delivery.

Hackworth, J. (2002) Local autonomy, bond-rating agencies and neoliberal urbanism in the United States. International Journal of Urban and Regional Research, 26(4), pp.707-725.

Hackworth, J. (2007) The Neoliberal City: Governance, Ideology and Development in American Urbanism. Cornell University Press, Ithaca.

Hall, T. \& Hubbard, P. (1996) Entrepreneurial City: New Urban Politics, New Urban Geographies? Progress in Human Geography, 20(2), pp.153-174.

Harvey, D. (1989) From managerialism to entrepreneurialism: the transformation in urban governance in late capitalism. Geografiska Annaler. Series B. Human Geography, pp.3-17.

Harvey, D. (1999) The Limits to Capital, Verso.

Hodkinson, S. \& Essen, C. (2015) Grounding accumulation by dispossession in everyday life International Journal of Law in the Built Environment, 7(1), pp.72-91.

Kirkpatrick, L.O. \& Smith, M.P. (2011) The Infrastructural Limits to Growth: Rethinking the Urban Growth Machine in Times of Fiscal Crisis. International Journal of Urban and Regional Research, 35(3), pp.477-503.

Lambeth. (2015a) Homes for Lambeth: A Special Purpose Vehicle for Lambeth, Available at: 
https://moderngov.lambeth.gov.uk/documents/s77350/Homes for Lambeth an SPV for Lambeth.pdf.

Lambeth. (2015b) "Homes for Lambeth": Lambeth's SPV to build more and better homes. Available at:http://estateregeneration.lambeth.gov.uk/_homes_for_lambeth_lambeth_s_spv_to_build_ more_and_better_homes.

Leitner, H. (1990) Cities in pursuit of economic growth. Political Geography Quarterly, 9(2), pp.146170.

Logan, J.R. \& Molotch, H.L. (1987) Urban Fortunes: The political economy of space, Berkeley: University of California Press.

MacLeod, G. \& Jones, M. (2011) Renewing Urban Politics. Urban Studies, 48(12), pp.2443-2472.

Newman, K. (2009) Post-Industrial Widgets: Capital Flows and the Production of the Urban. International Journal of Urban and Regional Research, 33(2), pp.314-331.

O'Neill, P. (2009) Infrastructure Investment and the Management of Risk. In Managing Financial Risks. Oxford University Press, pp. 163-188.

O'Neill, P.M. (2015) Infrastructure's Stubborn Spatiality and its Maturing Financialization. SSRN Electronic Journal.

Pacewicz, J. (2013) Tax increment financing, economic development professionals and the financialization of urban politics. Socio-Economic Review, 11(3), pp.413-440.

Peck, J. (2016) Transatlantic city, part 1: Conjunctural urbanism. Urban Studies, 54(1), pp.4-30.

Peck, J. \& Whiteside, H. (2016) Financializing Detroit. Economic Geography.

Penny, J. (2016) Between coercion and consent: the politics of "Cooperative Governance" at a time of "Austerity Localism" in London. Urban Geography, 0(0), pp.1-22.

PriceWaterhouseCoopers. (2011) The next chapter Creating an understanding of Special Purpose Vehicles

Rutland, T. (2010) The financialization of urban redevelopment. Geography Compass, 4(8), pp.11671178.

Sandford, M. (2016) Public services and local government: the end of the principle of 'funding following duties'. Local Government Studies, 42(4), pp.637-656.

Tickell, A. (1998) Creative finance and the local state. Political Geography, 17(7), pp.865-881.

Torrance, M.I. (2008) Forging Glocal Governance? Urban Infrastructures as Networked Financial Products. International Journal of Urban and Regional Research, 32(1), pp.1-21.

Watt, P. (2009) Housing stock transfers, regeneration and state-led gentrification in London. Urban Policy \& Research, 27(3), pp.229-242.

Weber, R. (2010) Selling City Futures : The Financialization of for their cooperation and. Economic Geography, 86(3), pp.251-274. 